\title{
Participatory Evaluation of Productivity, Fertility Management, and Dissemination of Irrigated Exotic Vegetables in the Sahel, West Africa
}

\author{
Hide Omae ${ }^{1}$, Addam Kiari Saidou2, Kimio Osuga3 ${ }^{3}$, Haruyuki Dan³, Satoshi Tobita4 \\ ${ }^{1}$ Tropical Agriculture Research Front (TARF), Japan International Research Center for Agricultural Sciences \\ (JIRCAS), Ishigaki, Japan \\ ${ }^{2}$ National Institute of Agronomic Research of Niger (INRAN), Niamey, Niger \\ ${ }^{3}$ Rural Development Division, JIRCAS, Tsukuba, Japan \\ ${ }^{4}$ Crop, Livestock and Environment Division, JIRCAS, Tsukuba, Japan \\ Email: " homae@affrc.go.jp
}

Received 15 September 2015; accepted 26 October 2015; published 29 October 2015

Copyright (C) 2015 by authors and Scientific Research Publishing Inc.

This work is licensed under the Creative Commons Attribution International License (CC BY).

http://creativecommons.org/licenses/by/4.0/

c) (i) Open Access

\begin{abstract}
We conducted on-farm participatory experiments and activities for 3 years at three sites in the Fakara district of western Niger to demonstrate, verify, and evaluate crop productivity due to fertilizer application, economic benefits, and the dissemination of crop technology. We tested combinations of manure and mineral fertilizer on 13 exotic vegetables: bell pepper, cabbage, carrot, chili, eggplant, lettuce, melon, onion, potato, pumpkin, sweet potato, tomato, and zucchini. Farmers' selectivity was evaluated as the number of plots that farmers selected to carry out their own trials. The application of $110 \mathrm{~kg} \cdot \mathrm{N} / \mathrm{ha}$ manure plus $13.7 \mathrm{~kg} \cdot \mathrm{N} / \mathrm{ha}$ mineral fertilizer increased overall vegetable yields by $161 \%(P<0.01)$. The improvement of soil fertility increased the yield of subsequent rainfed millet by $124 \%(P<0.05)$. Less-experienced female farmers could afford to grow cabbage, onion, lettuce, potato, and pumpkin, which yielded $4.8-11.4$ t/ha fresh weight. Daily management by women in the vegetable gardens gave regular opportunities to chat and thus disseminate the technology.
\end{abstract}

\section{Keywords}

Participatory Approach, Irrigated Vegetable Production, Sahel

\footnotetext{
${ }^{*}$ Corresponding author.
}

How to cite this paper: Omae, H., Saidou, A.K., Osuga, K., Dan, H. and Tobita, S. (2015) Participatory Evaluation of Productivity, Fertility Management, and Dissemination of Irrigated Exotic Vegetables in the Sahel, West Africa. Agricultural Sciences, 6, 1272-1282. http://dx.doi.org/10.4236/as.2015.610122 


\section{Introduction}

The poor productivity of agro-pastoral systems in the Sahel, West Africa, has prompted numerous research and development projects concerned with soil fertility, land degradation, and desertification [1]. Between $80 \%$ and $90 \%$ of the population in the Sahel live by rainfed agriculture, producing a limited number of staple crops (millet, sorghum, groundnuts, and cowpeas) in the rainy season (June-September). Because of population growth (around 3\% per year), there is a need to identify innovative alternatives for increasing productivity and for managing soil fertility such as the effective use of water resources and fertilizer [2] in the off-season. Demand for exotic vegetables has been rising with increasing consumption of fruit and vegetables due to urbanization, and vegetable production contributes to poverty reduction [3]-[5]. Despite the economic advantage of exotic vegetable production, little has been published on productivity and fertilizer application in the Sahel. In addition, there are few reports on the effective use of vegetable gardens in improving regional land productivity. Dryseason vegetable production offers an additional advantage of employing women [6]-[10]. Women are challenged as much as men by diminished agricultural yields [11]. The situation has increased male migration to cities to find work, making women's roles in production essential to household and community survival [12]. Attempting to ensure food sufficiency, women supplement family earnings through small-scale income-generating activities such as the production of charcoal, the processing of shea butter, and market gardening. Yet the transfer of new technologies and extension services seldom involve women farmers [13]. As a solution, the "motherbaby trial" approach offers an on-farm participatory means to introduce and test a range of technology options suited to heterogeneous communities [14]. The "mother" trial is to test a range of technologies and research hypothesis under research management. The "baby" trial, on the other hand, comprises a number of satellite trials of large plots under farmer management and farm resources. The mother-baby trial, therefore, generates data on the performance of alternative technologies, creates the basis for dialogue between farmers and researchers, and encourages subsequent experimentation by farmers [15].

The objectives of this study were 1) to evaluate the productivity of exotic vegetables due to fertilizer application and the economic benefit for female farmers in the production of irrigated exotic vegetables; 2) to identify land productivity by the multiple-use cultivation of vegetable gardens; and 3) to evaluate methods for the dissemination of irrigated vegetable production by women in the Sahel.

\section{Materials and Methods}

\subsection{Site Description}

On-farm experiments and trials were conducted as mother-baby trials [14] in irrigated conditions during 2008-09, 2009-10, and 2010-11 in three villages (Maourey Kouara Zeno: $13^{\circ} 35.61 ' \mathrm{~N}, 2^{\circ} 39.03^{\prime} \mathrm{E}$; Yerimadey: $13^{\circ} 29.11^{\prime} \mathrm{N}, 2^{\circ} 41.30^{\prime} \mathrm{E}$; Bokossay: $13^{\circ} 25.72^{\prime} \mathrm{N}, 2^{\circ} 47.32 \mathrm{E}$ ) in the Fakara district, Dantiandou commune, Tillaberi region, western Niger, about $50 \mathrm{~km}$ northeast of Niamey, the capital (Figure 1). The villages comprised 61 households in Maourey Kouara Zeno, 90 in Yerimadey, and 51 in Bokossay. The Zarma, the principal ethnic group of this area, are agriculturists engaged mainly in the rainfed production of grains such as millet (Pennisetum glaucum (L.) R.Br.) and cowpea (Vigna unguiculata (L.) Walp.). The prevailing soil type in the Fakara district is Psammentic Paleutalf type of which $90 \%$ is sand fraction, with a pH of 5.3, $0.16 \mathrm{~g} \cdot \mathrm{kg}^{-1}$ total nitrogen, $0.2 \%$ organic carbon, $4.1 \mathrm{mg} \cdot \mathrm{kg}^{-1}$ available phosphorus, and $1.2 \mathrm{cmol} \cdot \mathrm{kg}^{-1}$ effective CEC and typical characteristics of an infertile soil [16]-[18]. Rain falls from June until September, with a peak in August and total of about $550 \mathrm{~mm}$ [16]. From 2001 to 2008, the mean rainfall was $75.5 \mathrm{~mm}$ in September and $7.9 \mathrm{~mm}$ in October, little to none $(<0.5 \mathrm{~mm})$ to March, and $7.4 \mathrm{~mm}$ in April. The mean daily temperature ranged from $23.9^{\circ} \mathrm{C}$ to $30.2^{\circ} \mathrm{C}$ from September to February, $31.2^{\circ} \mathrm{C}$ in March, and $33.9^{\circ} \mathrm{C}$ in April.

Irrigated vegetable production starts in late September and ends in early April. The first season, thus, started from September in 2008 and ended in early April in 2009. The second season started from September in 2009 and ended in early April in 2010. Because of the location of available water resources and the need for daily management, especially irrigation, vegetables are grown on farms adjacent to each village (Figure 2). Wells are located at village center and used both for drinking and for irrigation. Metal fences protected the crops from animals at Mourey Koala Zeno and Yerimadey.

\subsection{Participatory Approach to Experiments, Demonstration, and Practices}

We used mother-baby trials to evaluate farmers' selectivity of the technologies. We set up experiments and 


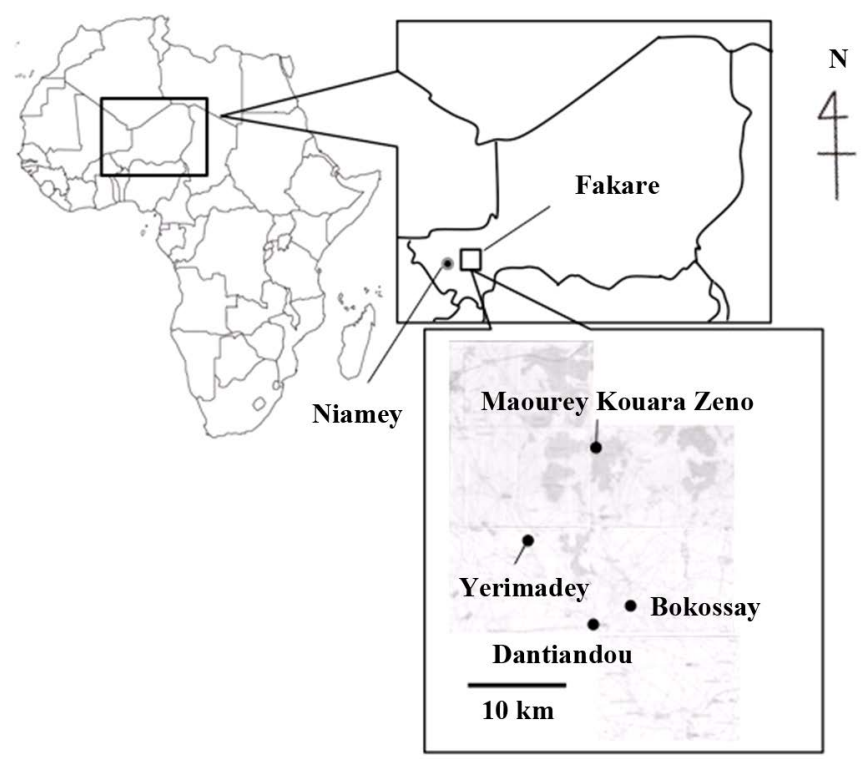

Figure 1. Location of the experiments and demonstration sites.
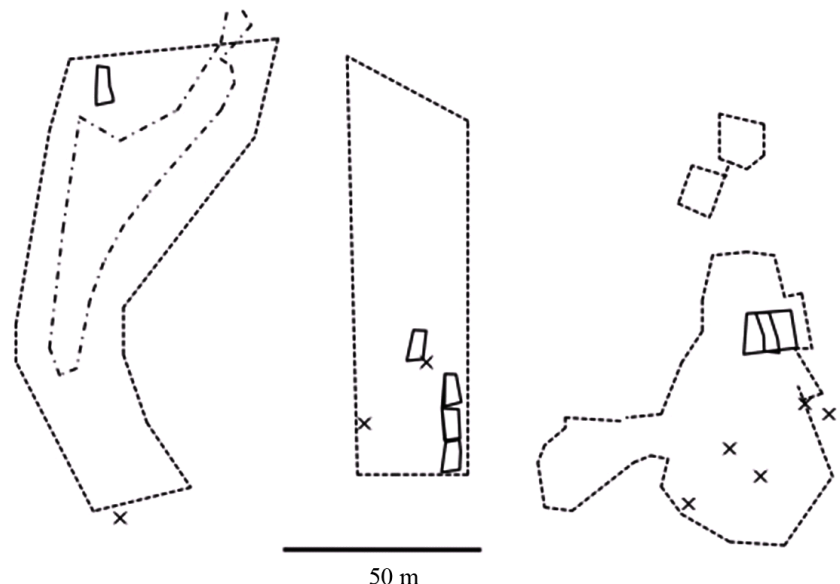

Maourey Koara Zeno, Yerimadey and Bokossay village from left to right

$$
\begin{aligned}
& \text { - Mother, Baby group fields } \\
& \text {-.- Pond } \\
& \times \text { Management area for vegetable }
\end{aligned}
$$

Figure 2. Location of dry-season-vegetable production in Maourey Koala Zeno, Yerimadey and Bokossay, Fakara, Niger.

demonstrations at one site in each village, which we regarded as the mother trial. Before setting up the mother fields, we conducted 1 to 3 days of farmer training in each village in March or April of 2008, 2009 and 2010. In this training, we presented the types and effects of organic and inorganic fertilizers, micro-dosing techniques [19] [20] for the application of mineral fertilizer, differences between traditional and advanced composts, characters of the exotic vegetables, sowing or planting methods for each crop, preparation and management of seedlings and so on. About 25 men and 25 women attended each meeting. After the training, we encouraged the farmers to practice the technologies of their choice on their farms, in what we regarded as baby trials. Groups of some farmers elected to conduct our trials exactly; we regarded these group baby trials as separate, and encouraged the farmers to apply fertilizer at half or quarter doses to avoid repetition and to test the effect of dose. Farmers who did not attend the training also conducted trials with reference of the activities of the baby-trial farmers; we regarded these as non-baby trials, and recorded them as well. The results of the mother trial in each year were presented to the farmers at a field day at the mother field in October to November in 2008 and 2009. The results 
of the baby trials were reviewed by the farmers at meetings in February 2009 and April 2010.

\subsection{Design of Field Experiments for Irrigated Vegetable Production}

In each mother field, three mid-sized plots $(3 \mathrm{~m} \times 4 \mathrm{~m})$ and ten small plots $(3 \mathrm{~m} \times 1 \mathrm{~m})$ were established in 2008 . Plots received one of four fertilizer treatments: manure, mineral fertilizer, both or neither. Thirteen vegetables were grown: bell pepper (Capsicum annuum L. var. angulosum), cabbage (Brassica oleracea L. var. capitata), carrot (Daucus carota L.), chili (Capsicum annuum “Acuminoum”), eggplant (Solanum melongena L.), lettuce (Lactuca sativa L.), melon (Cucumis melo L.), onion (Allium cepa L.), potato (Solanum tuberosum L.), pumpkin (Cucurbita maxima Duch.), sweet potato (Ipomoea batatas Poir), tomato (Solanum lycopersicum L.), and zucchini (Cucurbita pepo L.). The manure treatment comprised $9 \mathrm{t} / \mathrm{ha}$ of cow manure $(110 \mathrm{~kg} \cdot \mathrm{N} / \mathrm{ha})$ with respecting the way of farmers in this region. The mineral fertilizer treatment comprised $3 \mathrm{~g}$ of compound mineral fertilizer $(\mathrm{N}: \mathrm{P}: \mathrm{K}=15: 15: 15)$ at sowing and $2 \mathrm{~g}$ of urea $(13.7 \mathrm{~kg} \cdot \mathrm{N} / \mathrm{ha})$ per hill after one month of sowing according to the methodology and the recommended doses of micro-dosing technique [19] [20]. The manure + mineral fertilizer treatment comprised $9 \mathrm{t} / \mathrm{ha}$ of cow manure, $3 \mathrm{~g}$ of compound mineral fertilizer $(\mathrm{N}: \mathrm{P}: \mathrm{K}=15: 15: 15)$ at sowing, and $2 \mathrm{~g}$ of urea (123.7 kg. $\mathrm{N} / \mathrm{ha}$ in total) per hill after one month of sowing. Although the application dose of nitrogen differed among the treatments, we respected the ways of micro-dosing technique and farmers in this region and thus we did not adjust application doses to ensure a standardized amount of nitrogen. The experiments were conducted in a split-plot design with three replications (one per village). Seedlings of bell pepper, cabbage, chili, eggplant, lettuce, onion, and tomato were transplanted into the small plots at $0.3-\mathrm{m} \times 0.3-\mathrm{m}$ spacing about 2 weeks after sowing. Tubers or seedlings of potato and sweet potato were planted directly into the small plots at $0.3-\mathrm{m} \times 0.3-\mathrm{m}$ spacing, and those of melon, zucchini, and pumpkin into the mid-sized plots at 1.0-m $\times 1.0-\mathrm{m}$ spacing, and thinned to one plant per hill after 2 weeks. Seeds of carrot were sown in line in small plots. Crops were planted in September and harvested at physiological maturity from February to April. The plants were irrigated twice a day in morning and evening with a 24-litter of watering can from pond (Maourey Koala Zeno) or pumping wells. Weeding was conducted timely during the study period. The fresh biomass and yield were recorded in season 1 and 2.

In the group baby trials, in which we encouraged the farmers to apply fertilizers at half or quarter doses, all other details were the same as in the mother trials. The crops were sown and harvested with reference to the mother trials. For the baby trials, we encouraged the farmers to apply fertilizers at the same dose in the mother trials.

The differences between treatments were determined by ANOVA followed by Student's t-test in JMP version 9.0.0 software (SAS Institute, Cary, NC, USA).

\subsection{Design of Field Experiments for Subsequent Rainfed Millet Production}

Following the first season of irrigated vegetable production, we combined all plots into one big plot $(3 \mathrm{~m} \times 24 \mathrm{~m})$ in the mother fields. Each village had four such plots. In addition, we established another four such plots in fields with a history of rainfed grain cultivation. Each mother vegetable field and each mother rainfed grain field received one of the four fertilizer treatments, and a crop of millet ("Haini Tchirey", a local landrace; 120 days to harvest) was sown in each. The fertilizers were applied as in the vegetable experiments. The experiment was conducted in a split-plot design with three replicates (one per village). Millet was sown at $1.0 \mathrm{~m} \times 1.0 \mathrm{~m}$ in June 2009, thinned to three plants per hill after 2 weeks, and harvested at physiological maturity in October 2009. Millet plants were harvested and partitioned into ears and stalks. After drying, the ears were threshed and the total biomass was determined. All aboveground crop residues were removed from the plots at the end of the cropping season.

\subsection{Farmer Survey}

After training and before the baby trials in 2008, we interviewed the baby-trial and non-baby-trial farmers about them, their families, and their farms. After establishing the baby trials, we divided the data between the two groups.

To gauge the economic situation of the women, we visited an average of 24.3 female farmers in each village in 2008 and interviewed them about source of income and money in their possession. Additional farmers were interviewed if numbers were low. 


\subsection{Soil Sampling and Analysis}

Soil sampling and analysis were done according to Omae et al. [21].

\section{Results}

\subsection{Results of Mother and Group Baby Trials}

Both fertilizer application and vegetable type were similar between the mother and group baby trials (Table 1). The effects of both were significantly different when all results were averaged over seasons 1 and 2. Manure plus mineral fertilizer increased vegetable yields by $161 \%(P<0.01)$, followed by mineral fertilizer at $119 \%$ ( $P$ $<0.01)$. The yields of cabbage (11.4 t/ha) and onion ( $8.4 \mathrm{t} / \mathrm{ha})$ were highest, followed by lettuce, carrot, potato, and melon. The yields of cabbage and onion were significantly greater than those of pumpkin, eggplant, tomato, sweet potato, zucchini, chili, and bell pepper. The interaction between fertilizer and vegetable was significant in the group baby trials in season 1 .

In the group baby trials in season 1 , mineral fertilizer and manure plus mineral fertilizer increased yields by $190 \%-215 \%(P<0.01)$ relative to no fertilizer; the yields of cabbage $(10.2 \mathrm{t} / \mathrm{ha})$ and carrot $(9.7 \mathrm{t} / \mathrm{ha})$ were highest, followed by lettuce and pumpkin. In season 2, the yield of onion (13.0 t/ha) was highest, followed by potato, melon, and eggplant.

Manure plus mineral fertilizer applied to mother vegetable fields increased millet biomass by $115 \%(P<0.01)$ and yield by $118 \%(P<0.01)$ relative to no fertilizer (Table 2$)$. Manure plus mineral fertilizer applied at half

Table 1. Effects of fertilizer and vegetable type on yield in mother and group baby fields.

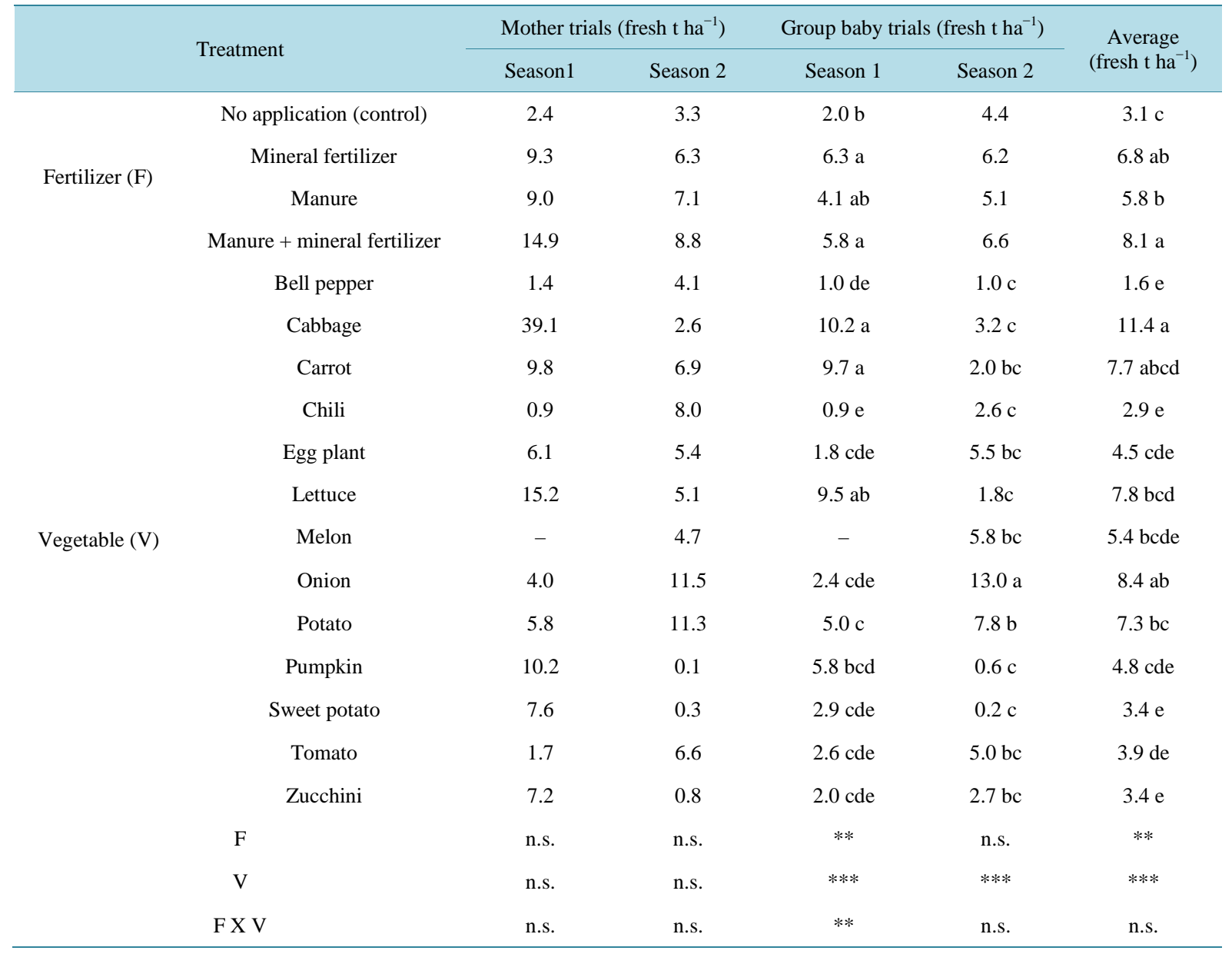

$* P<0.05,{ }^{* *} P<0.01,{ }^{* * *} P<0.001$, n.s. not significantly different. Values followed by the same letter are not significantly different at $P=0.05$ by Student's $t$-test. 
Table 2. Effect of fertilizer on millet production in rainy season, 2009.

\begin{tabular}{|c|c|c|c|}
\hline Site & Fertilizer (F) & Biomass $\left(\mathrm{kg} \cdot \mathrm{ha}^{-1}\right)$ & Yield $\left(\mathrm{kg} \cdot \mathrm{ha}^{-1}\right)$ \\
\hline Mother (veg.) & no application & 4319 cde & 559 bcdef \\
\hline Mother (veg.) & mineral & $8535 a b$ & $1036 \mathrm{abc}$ \\
\hline Mother (veg.) & manure & 6738 abc & 758 abcde \\
\hline Mother (veg.) & manure + mineral & 9307 a & 1221 a \\
\hline Group baby (veg.) & no application & 3764 cde & 393 def \\
\hline Group baby (veg.) & $1 / 2$ mineral & 6875 abc & $1036 \mathrm{abc}$ \\
\hline Group baby (veg.) & $1 / 2$ manure & 4932 bcde & 668 abcdef \\
\hline Group baby (veg.) & $1 / 2$ manure $+1 / 2$ mineral & 7286 abc & $1161 \mathrm{ab}$ \\
\hline Group baby (veg.) & no application & 4290 cde & 492 cdef \\
\hline Group baby (veg.) & $1 / 4$ mineral & $6763 \mathrm{abc}$ & 914 abcde \\
\hline Group baby (veg.) & $1 / 4$ manure & 5546 bcd & 595 bcdef \\
\hline Group baby (veg.) & $1 / 4$ manure $+1 / 4$ mineral & $7188 \mathrm{abc}$ & 768 abcde \\
\hline Mother (grain) & no application & 1379 e & $154 \mathrm{f}$ \\
\hline Mother (grain) & mineral & 2725 de & 399 ef \\
\hline Mother (grain) & manure & $5057 \mathrm{~cd}$ & 829 abcde \\
\hline Mother (grain) & manure + mineral & 4380 cde & 546 cdef \\
\hline \multicolumn{2}{|c|}{$\mathrm{F}$} & $* *$ & $*$ \\
\hline
\end{tabular}

${ }^{*} P<0.05,{ }^{* *} P<0.01$. Values followed by the same letters are not significantly different at $P=0.05$ by Student's $t$-test. "Veg." indicates mother rainfed vegetable fields. "Grain" indicates mother rainfed grain fields.

rate to group baby vegetable fields produced a similar increase in millet biomass (n.s.) and increased millet yield by $195 \%(P<0.05)$. Mineral fertilizer applied to mother vegetable fields increased millet biomass by $213 \%(P<$ $0.01)$ and yield by $160 \%(P<0.05)$ relative to that applied to mother rainfed grain fields. Similarly, manure plus mineral fertilizer applied to mother vegetable fields increased millet biomass by $112 \%(P<0.01)$ and yield by $124 \%(P<0.05)$ relative to that applied to mother rainfed grain fields. In the group baby fields, millet biomass and yields showed increasing trends with increasing fertilizer dose from quarter to full (Table 2).

Total N, organic C and Bray I P of no application plot in season 1 reflected initial soil condition of Fakara very well [18] except for $\mathrm{pH}$, which showed higher value due to be exposed to reducing condition by irrigation (Table 3). The no-fertilizer treatment significantly increased $\mathrm{pH}$ compared with fertilizers in season 1 . Manure increased total $\mathrm{N}$ by $137 \%(P<0.01)$ relative to no fertilizer in season 1 . It also increased total $\mathrm{N}$ by $83 \%$ relative to mineral fertilizer alone in season 1 , and by $55 \%(P<0.05)$ in season 2 . It increased organic $C$ by $150 \%$ $(P<0.01)$ relative to no application and mineral fertilizer alone in season 1 . Manure plus mineral fertilizer increased Bray I P by 53\% - 829\% $(P<0.001)$ relative to the other treatments, and increased total P by $18 \%-32 \%$ $(P<0.05)$ relative to no fertilizer and mineral fertilizer alone.

\subsection{Results of Individual Baby Trials}

There were no significant differences between baby-trial and non-baby-trial farmers in percentage of women, farmer age, cultivation area, numbers of plots, number of vegetable types, number of plants, fertilizer application, percentage of area cultivated, or years of experience (Table 4). In contrast, $74.8 \%$ of baby-trial farmers belonged to a farmers' group, versus only $13.3 \%$ of non-baby-trial farmers $(P<0.01)$. In both groups, about $75 \%$ of farmers were women. Both groups grew 3 to 4 vegetable types on $200-235 \mathrm{~m}^{2}$. Around $40 \%$ of both groups applied manure plus mineral fertilizer, while $33.7 \%$ - 49.1\% applied none. Both groups preferentially grew pumpkin (38.2\% - 57.5\%), followed by cabbage, onion, lettuce, and watermelon (Table 4(b)). Both groups had the longest experience with pumpkin (2.4 - 5.8 years), followed by watermelon, tomato and eggplant, zucchini, lettuce, onion, potato, and cabbage (Table 4(c)). 
Table 3. Effects of fertilizers on soil chemical properties in mother vegetable fields.

\begin{tabular}{|c|c|c|c|c|c|c|c|c|}
\hline \multirow{2}{*}{ Application (A) } & \multicolumn{2}{|c|}{$\mathrm{pH}\left(\mathrm{H}_{2} \mathrm{O}\right)$} & \multicolumn{2}{|c|}{ Total N (mg $\left.\cdot \mathrm{kg}^{-1}\right)$} & \multicolumn{2}{|c|}{ Organic C (\%CO) } & \multirow{2}{*}{$\begin{array}{c}\begin{array}{c}\text { Bray I P } \\
\left(\mathrm{mg} \cdot \mathrm{kg}^{-1}\right)\end{array} \\
\text { Season } 1\end{array}$} & \multirow{2}{*}{$\begin{array}{c}\begin{array}{c}\text { Total P } \\
\left(\mathrm{mg} \cdot \mathrm{kg}^{-1}\right)\end{array} \\
\text { Season } 2\end{array}$} \\
\hline & Season 1 & Season 2 & Season 1 & Season 2 & Season 1 & Season 2 & & \\
\hline No application (control) & $8.1 \mathrm{a}$ & 6.2 & $161.3 \mathrm{~b}$ & $178.7 \mathrm{ab}$ & $0.2 \mathrm{~b}$ & 0.2 & $4.9 \mathrm{c}$ & $118.0 \mathrm{bc}$ \\
\hline Mineral fertilizer & $6.8 \mathrm{~b}$ & 6.4 & $208.7 \mathrm{~b}$ & $137.6 \mathrm{~b}$ & $0.2 \mathrm{~b}$ & 0.2 & $29.7 \mathrm{~b}$ & $105.3 \mathrm{c}$ \\
\hline Manure & $7.2 \mathrm{~b}$ & 6.1 & 382.0 a & 213.9 a & $0.5 \mathrm{a}$ & 0.2 & $15.1 \mathrm{c}$ & $134.0 \mathrm{ab}$ \\
\hline Manure + mineral fert. & $7.3 \mathrm{ab}$ & 6.2 & 371.0 a & 199.6 a & $0.4 \mathrm{a}$ & 0.2 & $45.5 \mathrm{a}$ & 139.3 a \\
\hline A & $*$ & n.s. & $* *$ & * & $* *$ & n.s. & $* * *$ & $*$ \\
\hline
\end{tabular}

${ }^{*} P<0.05,{ }^{*} P<0.01,{ }^{* * *} P<0.001$, n.s. not significantly different. Values followed by the same letter are not significantly different at $P=0.05$ by Student's $t$-test.

Table 4. (a) Vegetable farmer statistics in 2008. (b) Area of irrigated vegetable cultivation by individual farmers. (c) Years of experience with irrigated exotic vegetable cultivation.

(a)

\begin{tabular}{ccccccccccccc}
\hline & \multirow{2}{*}{$\begin{array}{c}\text { Female } \\
(\%)\end{array}$} & Age & Farmer & Cultivation area & No. plots & No. vegetable & No. & \multicolumn{4}{c}{ Fertilizer application (\%) } \\
group $\left(\mathrm{m}^{2} /\right.$ farmer $)$ & cultivated & types & plants & $\begin{array}{c}\text { Manure }+ \\
\text { mineral }\end{array}$ & Manure & Mineral & No. \\
\hline Baby $^{\mathrm{a}}$ & 75.9 & 38.7 & $74.8 \mathrm{a}$ & 200.3 & 11.2 & 3.7 & 377.4 & 39.6 & 24.6 & 2.0 & 33.7 \\
Non-baby $^{\mathrm{b}}$ & 75.0 & 33.0 & $13.3 \mathrm{~b}$ & 235.7 & 11.5 & 3.4 & 258.5 & 40.3 & 7.0 & 3.7 & 49.1 \\
& n.s. & n.s. & $* *$ & n.s. & n.s. & n.s. & n.s. & n.s. & n.s. & n.s. & n.s. \\
\hline
\end{tabular}

${ }^{\mathrm{a}}$ Mean of 43.3 farmers. ${ }^{\mathrm{b}}$ Mean of 40.5 farmers. ${ }^{* *} P<0.01$, n.s. not significantly different. Values followed by the same letters are not significantly different at $P=0.05$ by Student's $t$-test.

(b)

\begin{tabular}{|c|c|c|c|c|c|c|c|c|c|c|c|c|c|c|c|c|}
\hline & \multicolumn{16}{|c|}{ Cultivation area \% } \\
\hline & pumpkin & onion & cabbage & lettuce & watermelon & potato & tomato & chili & $\begin{array}{l}\text { sweet } \\
\text { pepper }\end{array}$ & zucchini & $\begin{array}{l}\text { egg } \\
\text { plant }\end{array}$ & carrot & $\begin{array}{c}\text { bell } \\
\text { pepper }\end{array}$ & bean & hibiscus & melon \\
\hline Baby $^{a}$ & 38.2 & 21.3 & 18.5 & 9.2 & 3.5 & 2.9 & 1.9 & 1.0 & 1.0 & 0.8 & 0.7 & 0.4 & 0.3 & 0.1 & 0.0 & 0.0 \\
\hline \multirow[t]{2}{*}{$\begin{array}{l}\text { Non- } \\
\text { baby }^{b}\end{array}$} & 57.5 & 5.7 & 16.9 & 3.0 & 7.3 & 0.7 & 2.1 & 2.1 & 1.3 & 1.9 & 1.5 & 0.0 & 0.0 & 0.1 & 0.1 & 0.0 \\
\hline & n.s. & n.s. & n.s. & n.s. & n.s. & n.s. & n.s. & n.s. & n.s. & n.s. & n.s. & n.s. & n.s. & n.s. & n.s. & n.s. \\
\hline
\end{tabular}

${ }^{\mathrm{a}}$ Mean of 43.3 farmers. ${ }^{\mathrm{b}}$ Mean of 40.5 farmers. n.s. not significantly different.

(c)

\begin{tabular}{|c|c|c|c|c|c|c|c|c|c|c|c|c|c|c|c|c|}
\hline & \multicolumn{16}{|c|}{ Years of experience } \\
\hline & pumpkin & onion & cabbage & lettuce & watermelon & potato & tomato & chili & $\begin{array}{l}\text { sweet } \\
\text { pepper }\end{array}$ & zucchini & $\begin{array}{l}\text { egg } \\
\text { plant }\end{array}$ & carrot & $\begin{array}{l}\text { bell } \\
\text { pepper }\end{array}$ & bean & hibiscus & melon \\
\hline Baby $^{a}$ & 5.8 & 3.5 & 3.0 & 3.6 & 3.9 & 2.6 & 4.0 & 0.0 & 0.0 & 2.0 & 4.0 & 0.0 & 0.0 & 0.0 & 0.0 & 0.0 \\
\hline \multirow[t]{2}{*}{$\begin{array}{l}\text { Non- } \\
\text { baby }\end{array}$} & 2.4 & 0.1 & 0.2 & 0.0 & 3.2 & 0.9 & 0.0 & 0.3 & 0.0 & 1.9 & 0.0 & 0.0 & 0.0 & 0.0 & 0.0 & 0.0 \\
\hline & n.s. & n.s. & n.s. & n.s. & n.s. & n.s. & n.s. & n.s. & n.s. & n.s. & n.s. & n.s. & n.s. & n.s. & n.s. & n.s. \\
\hline
\end{tabular}

${ }^{\mathrm{a}}$ Mean of 43.3 farmers. ${ }^{\mathrm{b}}$ Mean of 40.5 farmers. n.s. not significantly different.

The number of vegetable types grown increased by 105\% $(P<0.05)$ in season 1 relative to before the trials, returned to the basal level in season $2(P<0.05)$, and decreased by $85 \%$ in season 3 (n.s.) (Table 5). Before the trials, farmers grew pumpkin, onion, cabbage, lettuce, watermelon, tomato, and eggplant. Throughout the trial, they regularly grew pumpkin, cabbage, lettuce, onion, and potato. The percentage of farmers who applied manure plus mineral fertilizer in season 2 increased by 55\% relative to before the trials, and those who applied 
Table 5. Effect of participatory approach on activities of individual farmers engaged in irrigated vegetable production.

\begin{tabular}{cccccccccc}
\hline & $\begin{array}{c}\text { No. } \\
\text { farmers }\end{array}$ & $\begin{array}{c}\text { Cultivation area } \\
\text { (ha/village) }\end{array}$ & \multicolumn{2}{c}{$\begin{array}{c}\text { Type of vegetable cultivated } \\
\text { No. types } \\
\text { /village }\end{array}$} & \multicolumn{1}{c}{ Name of vegetable } & Manure + mineral & Manure & Mineral & Sales (CFA \\
francs/village)
\end{tabular}

none decreased by $85 \%$, although the differences were not significant. The farmers earned 244142 to 287125 CFA francs per village per year.

\section{Discussion}

\subsection{Productivity of Exotic Vegetables with Fertilizer Application}

Yields of cabbage and onion were highest, and yields of pumpkin, eggplant, tomato, sweet potato, zucchini, chili, and bell pepper were lowest, regardless of fertilizer application (Table 1). Manure plus mineral fertilizer increased overall vegetable yields by $161 \%$, followed by mineral fertilizer at $119 \%$. The biggest vegetable crop in Africa in 2013 was potato (30 $499 \mathrm{kt})$, followed by sweet potato $(20131 \mathrm{kt})$, tomato $(18649 \mathrm{kt})$, onion (9650 kt by dry weight), cabbage (4114 kt), green chilies and bell peppers (2874 kt), melons (2068 kt), and pumpkin (1990 kt) [22]. The production potential of potato, onion, cabbage, and melon in our trials is thus parallels vegetable production in Africa, but that of lettuce and carrot does not. Because lettuce and carrot can be grown more easily and harvested sooner than potato, onion, cabbage, and melon, they may offer an advantage in increasing yields by increasing plantings. Carrot, in particular, can be harvested early by thinning. This may be compatible with the minimal experience of the farmers with those crops (Table 4(c)).

The fresh biomass and yields of vegetables tended to increase as the rate of fertilizer increased (Table 2). This means that an upper limit on application rates was not reached. Excessive application of fertilizer has led to annual positive nutrient balances of $843 \mathrm{~kg} \cdot \mathrm{N} / \mathrm{ha}, 70 \mathrm{~kg} \cdot \mathrm{P} / \mathrm{ha}$, and $200 \mathrm{~kg} \cdot \mathrm{K} / \mathrm{ha}$ in urban and periurban agricultural systems in Niamey [23]. Similarly, annual surpluses of $85-882 \mathrm{~kg} \cdot \mathrm{N} / \mathrm{ha}, 109-196 \mathrm{~kg} \cdot \mathrm{P} / \mathrm{ha}$, and $20-306$ $\mathrm{kg} \cdot \mathrm{K} / \mathrm{ha}$ were applied in small-scale periurban vegetable farming in Hanoi, Vietnam [24]. These rates pose high risks of soil pollution [25]. The rates applied in our study $(110 \mathrm{~kg} \cdot \mathrm{N} / \mathrm{ha}$ as manure and $13.7 \mathrm{~kg} \cdot \mathrm{N} / \mathrm{ha}$ as mineral fertilizer) are less than the above reports. Further study will be needed to investigate the effects of fertilizer application and rates on soil pollution, and to determine ways to take up excess fertilizer such as through continuous cropping.

\subsection{Economic Benefit of Irrigated Vegetable Production by Women}

The women earned 244,142 to 287,125 CFA francs per village per year by irrigated vegetable production. This equates to 10 to 12 bags of millet per village, or $€ 5.2$ to $€ 6.9$ per woman (656 CFA franc $=€ 1$ ). Almost $90 \%$ of farmers $(n=73)$ stated that money is the biggest limitation on activities. Small businesses account for the largest proportion of income generation by women (30.5\%), followed by sales of agricultural products (17.2\%), labor (6.9\%), sales of legumes (4.5\%), sales of animals (3.4\%), non-local work (2.2\%), and sales of wild medicinal plants (1.1\%); the rest (34.0\%) work in all other areas. The women farmers have only $€ 1.8$ each in their pockets. In many parts of Africa, women and men operate separate income and expenditure, with women carrying the primary burden for the financing of children's welfare [6]. Women and children are rarely the beneficiaries of the income generated by cash crops; their present wellbeing is founded rather in subsistence farming. For wom- 
en to supplement their earnings, small-scale-income-generating activities must be supported.

\subsection{Land Productivity in Vegetable Cultivation}

Around $40 \%$ of farmers, both baby-trial and non-baby-trial, were already familiar with applying manure plus mineral fertilizers (Table 4(a)). This practice improved soil fertility (Table 3) and grain production in the following rainy season (Table 2). In mother vegetable fields also, manure plus mineral fertilizer increased millet biomass and millet yields.

In contrast to the low nutrient inputs and the negative NPK balances that generally prevail in West Africa [26] [27], some farmers apply very high rates of nutrients, leading to large nutrient surpluses [24] [28] [29]; high inputs of irrigation water and fertilizer have been recorded in Benin, Ghana, and Niger, in West Africa [23] [30] [31]. Continuous cropping is thus beneficial for the management of total soil fertility in the region, and can give women farmers, who lack access to sources of income in West Africa, as in Benin [9], more chance to earn incomes.

\subsection{Dissemination of Irrigated Vegetable Production by Women}

There was no significant different between baby-trial and non-baby-trial farmers in percentage of women, age, cultivation area, number of plots, number of vegetable types, number of plants, fertilizer application, percentage of area cultivated, or years of experience (Table 4). Because the location of water resources is limited, and the farmers gather every day to draw water for irrigation (Figure 2), the opportunity to chat may promote technical exchange and assist in the dissemination of farming technologies.

Although the use of manure plus mineral fertilizer fluctuated over time, there were no significant differences in usage (Table 5). Nevertheless, the farmers may see the advantage of this practice from the results of the mother trials (Table 1 ) and the baby trials (Table 2).

From the results of seasons 1 and 2, the women farmers were able to select the five vegetables that they preferred: pumpkin, cabbage, lettuce, onion, and potato (Table 5).

\section{Conclusions}

1) Manure plus mineral fertilizer increased the yields of all vegetables. 2) The improvement of soil fertility improved rainfed grain production. 3) Cabbage, onion, lettuce, potato, and pumpkin, which promise high yields, are affordable for the less-experienced women farmers to cultivate. 4) Daily management gives the women regular opportunities to chat and exchange information, and thus for dissemination of the technology.

\section{References}

[1] Schlecht, E. and Hiernaux, F.F. (2004) Beyond Adding up Inputs and Outputs: Process Assessment and up Scaling in Modeling Nutrient Flows. Nutrient Cycle and Agroecosystem, 70, 303-319. http://dx.doi.org/10.1007/s10705-004-0765-2

[2] Sander, J.H. and Shapiro, B. (2003) Crop Technology Introduction in Semi-Arid Sub-Saharan Africa: Performance and Future Strategy. Journal of Production, 9, 559-592. http://dx.doi.org/10.1300/J144v09n01_09

[3] Weinberger, K. and Lumpkin, T.A. (2007) Diversification into Horticulture and Poverty Reduction: A Research Agenda. World Development, 35, 1464-1480. http://dx.doi.org/10.1016/j.worlddev.2007.05.002

[4] Ruel, M. T., Minot, N. and Smith, L. (2005) Patterns and Determinants of Fruit and Vegetable Consumption in SubSaharan Africa: Amulticountry Comparison. International Food Policy Research Institute, World Health Organization (WHO).

[5] Drechsel, P. and Keraita, B. (2014) Irrigated Urban Vegetable Production in Ghana, Characteristics, Benefits and Risk Mitigation. 2nd Edition, International Water Management Institute (IWMI), Colombo, Sri Lanka.

[6] Grieco, M. and Apt, N.A. (2008) Gender and Agriculture in the Africa: The "Expert” Neglect of Local Practice, The Change Page: Gender and Agriculture. http://www.transportandsociety.com/changepage/genderandagriculture

[7] Drechsel, P., Hope, L. and Cofie, O. (2013) Gender Mainstreaming: Who Wins? Gender and Irrigated Urban Vegetable Production in West Africa. The Journal of Gender \& Water, 2, 14-17.

[8] Khaleel, M.S., Merghani, E.A. and Abbas, S.E. (2014) Contribution of the Women's Forestry Project to Rural Development in Shendi Area (Sudan). IOSR Journal of Humanities and Social Science, 19, 91-98. 
http://dx.doi.org/10.9790/0837-19259198

[9] Kinkingninboun-Medagbe, F.M., Diagne, A., Simtowe, F., Agboh-Noameshie, A.R. and. Adegbola, P.Y. (2010) Gender Discrimination and Its Impact on Income, Productivity, and Technical Efficiency: Evidence from Benin. Agriculture and Human Values, 27, 57-69. http://dx.doi.org/10.1007/s10460-008-9170-9

[10] Quisumbing, A.R. and Pandolffeli, L. (2010) Promising Approaches to Address the Needs of Poor Female Farmers: Resources, Constraints, and Interventions. World Development, 38, 581-592. http://dx.doi.org/10.1016/j.worlddev.2009.10.006

[11] International Fund for Agricultural Development (IFAD) (2001) Assessment of Rural Poverty: Western and Central Africa. IFAD, Rome.

[12] Ward, C., Ballif-Spanvill, B., Fuhriman, A., Solomon, Y. and Widdison-Jones, K. (2004) Weeding out Failed Practices: A Case Study of Community Gardens in Rural Mali. Human Ecology, 32, 509-522. http://dx.doi.org/10.1023/B:HUEC.0000043518.72108.bf

[13] International Fund for Agricultural Development (IFAD) (2000) Gender Perspective: Focus on the Rural Poor. IFAD, Rome.

[14] Snapp, S. (2002) Quantifying Farmer Evaluation of Technologies: The Mother and Baby Trial Design. In: Bellon, M.R. and Reeves J., Eds., Quantitative Analysis of Data from Participatory Methods in Plant Breeding, CIMMYT, Mexico, DF.

[15] Reddy, K.S., Mohanty, M., Rao, D.L.N., Rao, A.S., Blamey, F.P.C., Dalal, R.C., Dixit, S.K., Pandey, M. and Menzies, N.W. (2010) Development of Farmers' Participatory Integrated Nutrient Management Technology Using the MotherBaby Trial Approach, World Congress of Soil Science, Soil Solutions for a Changing World, Brisbane, 1-6 August 2010, 87-90. (Published on DVD)

[16] Hiernaux, P. and Ayantunde, A. (2004) The Fakara: A Semi-Arid Agro Ecosystem under Stress. Report of Research Activities, First Phase (July 2002-June 2004) of the DMP-GEF Program. International Livestock Research Institute, Nairobi.

[17] Oudwater, N. and Martin, A. (2003) Methods and Issues in Exploring Local Knowledge of Soils. Geoderma, 111, 387-401. http://dx.doi.org/10.1016/S0016-7061(02)00273-2

[18] Hayashi, K. (2005) Actual Situation of Local Soil Fertility Management on Agricultural Land in the Sahel, West Africa. JIRCAS Research Highlights, 9, 1-2.

[19] ICRISAT (2001) Grey to Green Revolution. ICRISAT Annual Report. Ratancheru, Andhra Pradesh, India, 1-48.

[20] Tabo, R., Bationo, A., Maimouna, D.K., Hassane O. and Koala, S. (2006) Fertilizer Micro-Dosing for the Prosperity of Small-Scale Farmers in the Sahel. Final Report, Global Theme on Agro ecosystems Report No. 23, ICRISAT, Niamey, Niger.

[21] Omae, H., Saidou, A.K. and Tobita, S. (2014) On-Farm Evaluation of Effect of Organic and Mineral Fertilizers on Biomass and Yield of Millet/Cowpea Intercrop in the Sahel, West Africa. Journal of Life Science, 8, 582-592.

[22] FAOSTAT [Homepage on the Internet]. FAO. http://faostat3.fao.org/faostat-gateway/go/to/home/E

[23] Diogo, R.V.C., Buerkert, A. and Schlecht, E. (2010) Horizontal Nutrient Fluxes and Food Safety in Urban and PeriUrban Vegetable and Millet Cultivation of Niamey, Niger. Niger Nutrient Cycling in Agro ecosystems, 87, 81-102. http://dx.doi.org/10.1007/s10705-009-9315-2

[24] Khai, N.M., Ha, P.O. and Oborn, I. (2007) Nutrient Flows in Small-Scale Peri-Urban Vegetable Farming Systems in Southeast Asia: A Case Study in Hanoi. Agriculture, Ecosystems \& Environment, 122, 192-202. http://dx.doi.org/10.1016/j.agee.2007.01.003

[25] Sangare, S.K., Compaore, E., Buerkert, A., Vanclooster, M., Sedogo, M.P. and Bielders, C.L. (2012) Field-Scale Analysis of Water and Nutrient Use Efficiency for Vegetable Production in a West African Urban Agriculture System. Nutrient Cycling in Agro Ecosystems, 92, 207-224. http://dx.doi.org/10.1007/s10705-012-9484-2

[26] Stoorvogel, J.J., Smaling, E.M.A. and Janseen, B.H. (1993) Calculating Soil Nutrient Balances in Africa at Different Scales. I-Supranational Scale. Fertilizer Research, 35, 227-235. http://dx.doi.org/10.1007/BF00750641

[27] Lesschen, J.P., Stoorvogel, J.J., Smaling, E.M., Heuvelink, G.B.M. and Veldkamp, A. (2007) A Spatially Explicit Methodology to Quantify Soil Nutrient Balances and Their Uncertainties at the National Level. Nutrient Cycling in Agro ecosystems, 78, 111-131. http://dx.doi.org/10.1007/s10705-006-9078-y

[28] Zhu, J.H., Li, X.L., Christie, P. and Li, J.L. (2005) Environmental Implications of Low Nitrogen Use Efficiency in Excessively Fertilized Hot Pepper (Capsicum frutescens L.) Cropping Systems. Ecosystems \& Environment Ecosystems and Environment, 111, 70-80. http://dx.doi.org/10.1016/j.agee.2005.04.025

[29] Thompson, R.B., Martinez-Gailan, C., Gallardo, M., Gimenez, C. and Fernandez, M.D. (2007) Identification of Irrigation and N Management Practices That Contribute to Nitrate Leaching Loss from an Intensive Vegetable Production 
System by Use of Comprehensive Survey. Agricultural Water Management, 89, 261-274. http://dx.doi.org/10.1016/j.agwat.2007.01.013

[30] Drechsel, P., Giordano, M. and Gyele, L. (2004) Valuing Nutrients in Soil and Water: Concepts and Techniques with Examples from IWMI Studies in the Developing World. Research Report 82. Colombo, International Water Management Institute, 41.

[31] Graefe, S., Schlecht, E. and Buerkert, A. (2008) Opportunities and Challenges of Urban and Peri-Urban Agriculture in Niamey. Outlook Agriculture, 37, 47-56. http://dx.doi.org/10.5367/000000008783883564 